\title{
CONSTRUCTION OF THE CARE NETWORK FOR SKIN LESIONS
}

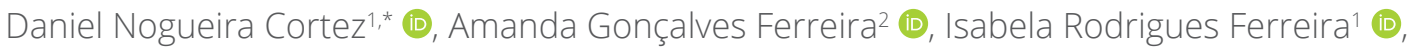 \\ Fernanda Moura Lanza' (D), Juliano Teixeira Moraes ${ }^{1}$ (1)
}

\begin{abstract}
Objective: describe the process of implementing the Rede de Atenção à Saúde em Lesões Cutâneas (Health Care Network for Skin Injuries) in the municipality of Divinópolis - MG. Method: it is an experience report on the implementation of a Health Care Network for Skin Injuries from the Programa de Educação Pelo Trabalho para Saúde (PET-Saúde/GraduaSUS) (Education Through Work for Health Program), from May 2016 to April 2018. Teachers and students from a public university and professional nurses linked to the Municipal Health Secretariat of the municipality participated in the actions. Results: it was possible to implement the Health Care Network for the prevention and treatment of skin lesions in a structured and systematic way. A flow of care, case supervision and clinical follow-up was established through the construction of an assistance protocol. Conclusion: the practical skill and scientific knowledge of students and health professionals for the treatment and management of skin lesions were developed, thus strengthening the teaching-service-community triad.
\end{abstract}

DESCRIPTORS: Community-institution relations. Access to health services. Health care. Wounds and injuries. Stomatherapy.

\section{CONSTRUÇÃO DA REDE DE ATENÇÃO PARA LESÕES CUTÂNEAS}

\section{RESUMO}

Objetivo: descrever o processo de implementação da Rede de Atenção à Saúde em Lesões Cutâneas no município de Divinópolis - MG. Método: trata-se de um relato de experiência sobre a implementação de uma Rede de Atenção à Saúde em Lesões Cutâneas a partir do Programa de Educação Pelo Trabalho para Saúde (PET-Saúde/ GraduaSUS), no período de maio de 2016 a abril de 2018. Participaram das ações professores e alunos de uma universidade pública e profissionais enfermeiros vinculados à Secretaria Municipal de Saúde do município. Resultados: foi possível implementar a Rede de Atenção à Saúde para prevenção e tratamento de lesões cutâneas de maneira estruturada e sistematizada. Foi estabelecido um fluxo de atendimento, supervisão de casos e acompanhamento clínico por meio da construção de um protocolo assistencial. Conclusão: a habilidade prática e o conhecimento científico de alunos e profissionais de saúde para o tratamento e manejo de lesões cutâneas foram desenvolvidos fortalecendo, assim, a tríade ensino-serviço-comunidade.

DESCRITORES: Relações comunidade-instituição. Acesso aos serviços de saúde. Assistência à saúde. Ferimentos e lesões. Estomaterapia.

1. Universidade Federal de São João del-Rei - Divinópolis (MG), Brazil.

2. Escola Superior de Ciências da Saúde - Secretaria de Estado de Saúde - Brasília (DF), Brazil.

*Correspondence author: danielcortez@ufsj.edu.br

Section Editor: Manuela de Mendonça F Coelho

Received: Dez. 17, 2020 | Accepted: Mar. 19, 2021

How to cite: Cortez DN; Ferreira AG; Ferreira IR; Lanza FM; Moraes JT. Construction of the care network for skin lesions. ESTIMA, Braz. J. Enterostomal Ther., 2021, 19: e0921. https://doi.org/10.30886/estima.v19.998_IN 


\section{CONSTRUCCIÓN DE LA RED DE ATENCIÓN PARA LESIONES CUTÁNEAS}

\section{RESUMEN}

Objetivo: Describir el proceso de implementación de la Red de Atención de Lesiones de la Piel en el municipio de Divinópolis-MG. Método: Se trata de un informe de experiencia sobre la implementación de una Red de Atención a la Salud Programa de educación a través del trabajo - Saúde / GraduaSUS, de mayo de 2016 a abril de 2018. Docentes y estudiantes de una universidad pública participaron de las acciones y enfermeras profesionales vinculadas al departamento municipal de salud de la Municipalidad. Resultados: Se logró implementar la Red de Atención a la Salud para la prevención y tratamiento de Lesiones de la Piel de manera estructurada y sistemática. Se estableció un flujo de atención, supervisión de casos y seguimiento clínico mediante la construcción de un protocolo de asistencia. Conclusión: Se desarrolló la habilidad práctica y el conocimiento científico de los estudiantes y profesionales de la salud para el tratamiento y manejo de las lesiones cutáneas fortaleciendo así la tríada docente-servicio-comunitaria.

DESCRIPTORES: Relaciones Comunidad-Institución. Acceso Universal a los Servicios de Salud. Prestación de Atención de Salud. Heridas y Traumatismos. Estomaterapia.

\section{INTRODUCTION}

Quality health care requires a strong decision by the managers of the Sistema Unico de Saúde-SUS (Unified Health System) in the organization of actions and services of different technological densities that, integrated through technical, logistical and management support systems, aim to guarantee the integrality of care in a care network ${ }^{1}$.

The Rede de Atenção à Saúde (RAS) is systematized to respond to specific health conditions through stages of care that may require continuity and comprehensiveness at different levels of care ${ }^{1}$.

The Atenção Primária à Saúde-APS (Primary Health Care) it is considered the main gateway and the articulating center for users' access to SUS, and RAS plays a central role in guaranteeing user access to the system, offering a variety of services, including monitoring, guidance and dressing. Therefore, the team requires knowledge and preparation to deal with all stages of the process, from prevention to treatment and rehabilitation².

However, assistance to chronic skin lesions is dynamic and must accompany the scientific and technological evolution of the area, which shows the importance of continuing professional training, in addition to being a constant need for the performance of work in APS 2 .

In this context, the Programa de Educação pelo Trabalho para a Saúde (PET-Saúde/GraduaSUS) appears as a proposal to promote changes in the training models of health professionals, stimulating the integration of teaching-service-community, collaborating with curricular changes in line with the National Curriculum Guidelines ${ }^{3}$ through internships and experiences contextualized in SUS, directed to the needs of the population and strengthening public health policies in the country4.

As the effective assistance to users with chronic skin lesions in APS depends on the technical training of professionals, the availability of appropriate therapeutic products and the work relationships involving the multidisciplinary ${ }^{5}$ team, with the support of medium and high complexity services, the Universidade Federal de São João del-Rei (UFSJ) developed a proposal for PET-Saúde/GraduaSUS which aimed to build the care network for skin lesions in the municipality of Divinópolis, Minas Gerais. The purpose of this article is to describe the implementation process of RAS.

\section{METHOD}

This is an experience report on the implementation of a RAS for skin lesions from PET-Saúde/GraduaSUS, held in the municipality of Divinópolis, Minas Gerais, from May 2016 to April 2018.

Reporting the experience that falls within the field of practice allows a reflection on the actions developed in a situation of professional experience. This, in turn, brings relevant contributions from the dialogue between the scientific community, public health professionals and users ${ }^{6}$. 
The activities were carried out in partnership with the Municipal Health Secretariat of Divinópolis, state of Minas Gerais. This is a municipality in the Midwest region of the state, which is a reference for medium and high complexity healthcare. It has an estimated population of 235,000 inhabitants and has 63 public health establishments. Of these, 42 are APS units, which are considered communication centers within an RAS. Also part of the network is a polyclinic and an emergency care unit (UPA) that works 24 hours a day.

In this scenario, PET-Saúde/GraduaSUS cutaneous lesions was implemented, developed by professors and students of undergraduate courses in nursing and medicine at the Universidade Federal de São João del-Rei, Centro Oeste Dona Lindu campus. The group was formed by a coordinator, three tutors, two preceptors (professionals with a higher education level), three scholarship students and three volunteer students.

For the development of activities, the following strategies were carried out: situational diagnosis of chronic injuries treated at APS; structuring of a cutaneous injury prevention and treatment commission, composed of professional nurses from the municipality; training of members of the cutaneous injury prevention and treatment commission; elaboration of the assistance protocol in the RAS for people with skin lesions; training for professionals involved in the care and care of these patients; and structuring the outpatient care center for people with skin lesions.

\section{RESULTS}

The health care of people with skin lesions has been developed by the UFSJ School of Nursing, through university extension projects and programs, whose main objective was to strengthen the APS to qualify the assistance in skin lesions.

In 2016, the institutional recognition of this team's work led to the approval of the proposal submitted to the PETSaúde/GraduaSUS 2016/2017 notice, which articulated its actions with the "Special program for the prevention and treatment of skin injuries" to strengthen teaching integration-service-community and, thus, implement the RAS (Health Care Network) in skin lesions in the municipality of Divinópolis.

In the period from 2017 to 2018, after the elaboration of the situational diagnosis, through the active search of the patients listed by the APS teams and support in medical records, it was possible to identify the population of the municipality with chronic skin lesions.

Understanding the profile of these patients allowed us to know the target population of the care service for people with chronic skin lesions of medium complexity. It is important to mention that the specialized service was designed to serve only the population enrolled in APS services in the municipality of Divinópolis.

For the APS to provide quality care focused on people with skin lesions ${ }^{7}$, the following actions were necessary:

a) Constitution of a "Commission for the Prevention and Treatment of Skin Injuries", composed of six nurses from APS, being the specialist coordinator in Stomatherapy (wounds, stomas and incontinence). The professors at PET-Saúde/ GraduaSUS were included in this committee as consultants and advisers in the process;

b) Update of the protocol for the treatment of chronic skin lesions for APS: after a cycle of theoretical and practical studies of the "Commission for the Prevention and Treatment of Skin Injuries", which lasted 12 months, it was prepared, approved and published in the Official Gazette (Diário Oficial) of the Municipality the "Protocolo de Enfermagem para Tratamento de Lesões Cutâneas na Atenção Primária” (Nursing Protocol for the Treatment of Skin Injuries in Primary Care), in which the construction of RAS in skin lesions in the municipality was foreseen. It is noteworthy that the protocol had the participation of the community represented by the Municipal Health Council, which approved it;

c) Training of professional nurses and nursing technicians of all APS teams in the city. At first, training took place following the approved protocol and subsequently, in a regionalized manner, each member of the commission responsible for an area of the municipality responds to doubts and maintains a permanent education with the APS teams. Therefore, the main topics addressed are: flowchart, dressing and coverings.

All of these actions were supported by the management of the Municipal Health Department, which was essential to guarantee the investments and resources necessary for the change and implementation of the RAS ${ }^{1}$. 
In the service of Atenção Secundária à Saúde-ASS (Secondary Health Care), the PET-Saúde/GraduaSUS assumed, together with the local team, formed by professionals from this service, the assistance and training activities of the professionals of APS, promoting the articulation between teaching, research and extension.

The opening of the skin lesions clinic at the Medical Specialties Center was made possible through a partnership between the Municipal Health Secretariat and UFSJ. The service was implemented in the physical structure of the Municipal Polyclinic, which is located in the city center, with easy access for the population.

The outpatient clinic had the purpose of offering support to the APS for diagnosis and treatment, in a proposal of shared care, mainly for people with refractory or stagnant lesions. Thus, it acted as a matrix support, training and qualification environment for health professionals and undergraduate and graduate students in nursing in Atenção Básica/Saúde da Família (Primary Care/Family Health).

The user, when admitted to the outpatient clinic, was submitted to a nursing consultation to assess the health status, disease and injury conditions, as established by the ethical and legal precepts of the profession. Subsequently, assistance was prescribed with the use of adequate coverage and, if necessary, adjuvant therapy (example: inelastic compressive therapy). The guidelines for self-care were still carried out.

Clinic management was the main tool used by the team, as it applied evidence-based practices to: a) ensure optimal clinical standards; b) increase efficiency; c) reduce the risks for users and professionals; d) provide effective services; and e) improve the quality of health care.

All conducts were shared with APS for the continuity of care, which performed the case management.

\section{DISCUSSION}

The RAS implemented was based on the joint work of teaching-service-community as it managed to unite the university through students and teachers with PET-Saúde/GraduaSUS, health professionals and managers in the municipality and the Municipal Health Council as a representative of the population. The organization of assistance to users with skin lesions in a network made it possible to build bonds of solidarity and cooperation, as well as to achieve better health outcomes ${ }^{6,7}$.

The development of assistance in the skin lesions outpatient clinic provided a space for active interaction between students and teachers with professionals from SUS services and with the community. By acting as matrix support, it ensures the specialized rear for the APS teams, thus providing an alternative of organizational arrangements for the management of health work and the defragmentation of assistance ${ }^{8,9}$.

The student was the main author for his technical training, acquiring skills necessary for professional performance and his citizen training through teaching, research and extension activities, which enabled the acquisition of experiences that go beyond the theory taught in the classroom. Thus, it allowed an expanded understanding of the term integrality, of the bond, of welcoming, of affectivity and respect, promoting reflection on practices and actions as future health professionals ${ }^{2}$.

From situations experienced in this scenario, it was possible to develop the capacity for critical reflection about the quality of care and care, promoting, also, among those involved the feeling of uneasiness, discomfort and curiosity in the desire to seek effective solutions ${ }^{8}$.

The care in chronic skin lesions requires that health professionals have a reflection of the practice performed based on updates and scientific evidence, and with the commitment to offer quality care, in addition to optimizing available resources ${ }^{10}$. Still, the search for sources of professional updating, such as congresses and courses are incipient, which can compromise the quality of care ${ }^{10}$.

PET-Saúde/GraduaSUS presents itself as an alternative that collaborates in the implementation of RAS for skin lesions, because through the academic effort imbricated in the health service, it proposes to articulate activities that encourage and facilitate such implementation ${ }^{11}$. Among the activities can be cited: meetings with APS teams and a cutaneous injury prevention and treatment commission to discuss cases attended at the outpatient clinic; 
training with active methodologies for nurses from APS; discussion of clinical cases with network professionals; and academic seminars.

In line with the work between service-teaching-community and implantation of the RAS, the group also promoted the II Regional Symposium on Updating in the Care and Treatment of Wounds in the Midwest of Minas Gerais, which aimed to promote reflection on the advances and challenges in the prevention and treatment of injuries, and had the participation of health professionals from 54 municipalities in the central-west region of Minas Gerais.

It is evident that permanent and continuous education provides gradual changes in the complex reality of health services and should be understood as a resource to mediate changes, allowing subjects to self-assess at work, through work and beyond work, as a possibility of learning to deal with the world ${ }^{12,13}$.

The implementation of the RAS provided, in addition to the training of competent professionals, academic staff and scientific research skills, the qualification of the assistance policy for people with skin lesions, already in force in the local health system, aiming at a better quality of life for the population.

The work in the RAS is still considered incipient in much of Brazil, but it is known that it can be considered as a preponderant for the effectiveness of SUS ${ }^{1}$. Despite the limits for the practice of RAS for skin lesions in the municipality, a new look was launched on the need to reorganize health work.

\section{CONCLUSION}

The implementation of RAS for people with skin lesions was an important component that articulated teaching-servicecommunity, focusing on the development of health care and change in the process of training new health professionals and updating those who are in the daily life of the assistance in the services of APS.

The actions carried out in the three stages of the RAS execution process in cutaneous lesions allowed to strengthen the APS for resolutive action in the prevention, diagnosis and treatment of cutaneous lesions, being responsible for coordinating care to a service of superior technological density according to criteria defined in the municipal protocol guidelines.

Thus, the objective of the RAS was reached, which is "to promote the systemic integration of health actions and services, with the provision of continuous, comprehensive, quality, responsible and humanized care, as well as to increase the performance of the system in terms of access , equity, clinical and health efficacy and economic efficiency".

In this sense, students have fostered an expanded view of health care, enabling a better understanding of work processes and shared care practices.

\section{AUTHORS ‘CONTRIBUTION}

Conceptualization: Cortez DN and Moraes JT; Methodology: Cortez DN, Ferreira AG, Ferreira IR, Lanza FM and Moraes JT; Research: Ferreira AG and Ferreira IR; Writing - First version: Cortez DN, Ferreira AG, Lanza FM and Moraes JT; Writing - Review \& Editing: Cortez DN, Ferreira AG, Ferreira IR, Lanza FM and Moraes JT; Supervision: Cortez DN and Moraes JT.

\section{DATA STATEMENT AVAILABILITY}

Not applicable.

\section{FUNDING}

Ministério da Saúde. Programa de educação pelo trabalho para a saúde (PET-Saúde/GraduaSUS) - 2016/2017. Notice no13 of September 28, 2015. 


\section{ACKNOWLEDGEMENTS}

Secretaria Municipal de Saúde of Divinópolis/MG

\section{REFERENCES}

1. Mendes EV. As redes de atenção à saúde. Ciênc saúde coletiva 2010;15(5):2297-305. https://doi.org/10.1590/S141381232010000500005

2. Velôso RBP, Fernandes JD, Silva RMO, Cordeiro ALAO, Silva GTR, Silva EAL. Contribuições do Programa de Educação pelo Trabalho aos preceptores da Atenção Primária à Saúde. Rev esc enferm USP 2020;54:e03596. https://doi.org/10.1590/s1980$220 \times 2018055903596$

3. Magnago C, França T, Belisário SA, Santos MR. PET-Saúde/GraduaSUS na visão de atores do serviço e do ensino: contribuições, limites e sugestões. Saúde debate 2019;43(spel):24-39. https://doi.org/10.1590/0103-11042019s102

4. Rézio LA, Caetano DAF, Borges FA, Fortuna CM. O Pet-Redes como transformador das práticas profissionais de um Centro de Atenção Psicossocial. Interface (Botucatu) 2017;21(60):89-98. https://doi.org/10.1590/1807-57622016.0109

5. Silva MVS, Miranda GBN, Andrade MA. Sentidos atribuídos à integralidade: entre o que é preconizado e vivido na equipe multidisciplinar. Interface (Botucatu) 2017;21(62):589-99. https://doi.org/10.1590/1807-57622016.0420

6. Chibante CLP, Santo FHE, Santos TD, Porto IS, Daher DV, Brito WAP. Saberes e práticas no cuidado centrado na pessoa com feridas. Esc Anna Nery 2017;21(2):e20170036. Available at: https://www.scielo.br/pdf/ean/v21n2/1414-8145-ean-21 02-e20170036.pdf

7. Cortez DN, Moraes JT, Ferreira IR, Silva EL, Lanza FM. Custos do tratamento de lesões cutâneas na Atenção Primária à Saúde. ESTIMA, Braz J Enterostomal Ther 2019;17:e2419. https://doi.org/10.30886/estima.v17.824_PT

8. Faria L, Quaresma MA, Patiño RA, Siqueira R, Lamego G. Integração ensino-serviço-comunidade nos cenários de práticas na formação interdisciplinar em Saúde: uma experiência do Programa de Educação pelo Trabalho para a Saúde (PET-Saúde) no sul da Bahia, Brasil. Interface (Botucatu) 2018; 22(67):1257-66. https://doi.org/10.1590/1807-57622017.0226

9. Soares DJ, Rivemales MCC. Apoio matricial na gestão do trabalho da atenção primaria à saúde: uma revisão integrativa. J nurs health 2019;9(2):e199207. https://doi.org/10.15210/jonah.v9i2.14517

10. Carnut L. Cuidado, integralidade e atenção primária: articulação essencial para refletir sobre o setor saúde no Brasil. Saúde debate 2017;41(115):1177-86. http://doi.org/10.1590/0103-1104201711515

11. Bandeira LA, Santos MC, Duarte ERM, Bandeira AG, Riquinho DL, Vieira LB. Redes sociais de portadores de lesão cutânea crônica: o cuidado de enfermagem. Rev Bras Enferm 2018;71(Supl.1):697-705. http://doi.org/10.1590/0034-7167-2017-0581

12. Vieira CPB, Araújo TME. Prevalência e fatores associados a feridas crônicas em idosos na atenção básica. Rev esc enferm USP 2018;52:e03415. https://doi.org/10.1590/s1980-220x2017051303415

13. Pascon DM, Otrenti E, Mira VL. Percepção e desempenho de graduandos de enfermagem em avaliação de metodologias ativas. Acta paul enferm 2018;31(1):61-70. https://doi.org/10.1590/1982-0194201800010 